\title{
Measurement of Online Shopping Service Quality: From the Perspective of E-Commerce Law
}

\author{
Cheng-Kuang Wang ${ }^{1,2}, \mathrm{Bi}^{-R u}$ Lee $^{2}$, Run-Liang Feng ${ }^{1}$ \\ ${ }^{1}$ Law School, Nankai University, Tianjin 300071, China \\ ${ }^{2}$ Zhongshan Institute, University of Electronic Science and Technology of China, Guangdong 528402, \\ China
}

richardkuang@yahoo.com.tw, maggen_lee@hotmail.com,1217581043@qq.com

\begin{abstract}
E-Commerce is a general term for commercial transaction or other types of business on the virtual network using the Internet as medium. The key factors for the success of online stores are not only the presentation on the WEB page or the low price strategy, but also the good quality of online service. The Importance-Performance Analysis (IPA) is an approach that is often used to measure performance and analyze competitive strategies. This study uses the IPA approach to analyze the service quality of online shopping provided by the case company, introduces nine indicators to measure the service quality of online shopping and puts forward suggestions for the competitive strategy as the basis for the improvement of competitive strategy of the case company.
\end{abstract}

Keyword: Online Shopping, Importance-Performance Analysis Model, Service Quality, Competitive Strategy, E-Commerce Law

\section{Introduction}

Facing the diversity of customer's online shopping patterns, the existing online traders must focus on and understand various demands of consumers and be committed to improving the consumer's browsing rate and actively increasing the site's re-visit rate which will be converted into real transactions to gain profits. For new online shopping traders, since the threshold of this industry is not high and the competition of online market is quite intense, they have to determine market positioning and segment accurately and avoid imitations of products and business model in order to establish unique competitive advantages.

E-Commerce is a general term for commercial transaction or other types of business on the virtual network using the Internet as medium. The E-Commerce system is divided into different types according to the scope of business functions and the types of customers. Common types are as follows[1,2]:

1) Business to Business, B2B: The interactions between businesses. The suppliers, customers and relevant businesses with common goals are joined together; the supply chain is converted into the business resource planning management in order to save costs and increase efficiency.

2) Business to Customers, B2C: Business-to-customer sales activities. The businesses put products on the Internet, conduct sales activities through the Internet and provide adequate information and interfaces to attract customers and offer them the online ordering service of products.

3) Customer to Customer, $\mathrm{C} 2 \mathrm{C}$ : Most of the parties of the transactions are not wholesalers or retailers. Most of them only want to sell their own products, so they conduct transactions in this type of trading market. The website operators are not responsible for the logistics. They only establish the trading platform to help the commodity aggregation of the market. Buyers and sellers are responsible for the transaction process.

4) Customers to Business, $\mathrm{C} 2 \mathrm{~B}$ : The products dominance is transferred from manufactures to consumers. Consumers should establish a community first, then find business opportunities through the collective bargaining of the community. The $\mathrm{C} 2 \mathrm{~B}$ model emphasizes the use of the demand aggregator to replace the traditional shopping centers where suppliers are gather.

Zeithaml, Parasuraman \& Malhotra[3] proposed that the key factors for the success of online stores were not just the presentation on the WEB page or the low price strategy, but also the good quality of online 
service. Rust and Kannan[4] argued that the services provided by online stores were not just the implementation of transaction orders or the instant answers to customer's questions. Real online service can provide customers with an experience of information interaction and serves as a way to improve the satisfaction and loyalty of customers[5].

Importance-Performance Analysis is an approach that is often used to measure performance and analyze competitive strategies. This study uses the IPA approach to analyze the service quality of online shopping provided by the case company so as to improve the competitive strategy of the case company.

\section{Literature Review}

\subsection{The service quality of online shopping}

Zeithaml, Parasuraman \& Malhotra[6] argued that the traditional dimensions of e-service quality did not apply to the online trading environment, because the traditional transaction was communicated through people, but the online transaction interacted with customers through the website and the cognition of service quality was different.

Parasuraman, Zeithaml and Malhotra[7] defined "e-Service Quality, or e-SQ" clearly. They believed that e-SQ was "the ability of the website to increase the efficiency and effectiveness of shopping, products and service delivery".

Parasuraman et al. (2005) developed the following seven important e-service quality dimensions: Efficiency, Reliability, Fulfillment, Privacy, Responsiveness, Compensation, and Contact.

Generally, the e-service quality can be summarized as: the degree of customer's overall evaluation of the shopping service after the providers of online shopping service provide service for customers through the special environment of "Internet". In addition, the process of shopping online, the delivery of products and other process also belong to the e-service quality.

In order to improve traditional service quality measurement methods, increase the effectiveness of measurement results and analyze the business strategy of shopping websites, this study refers to the dimensions introduced by Parasuraman et al. (2005), develops the nine measurement indicators for online shopping service quality to measure the service quality of online shopping and puts forward suggestions for competitive strategy. Please refer to Table 1 for details of the nine indicators.

\section{Research Approach}

The basic structure of Importance-Performance Analysis (IPA) was first introduced and put into use by Martilla and James[5]. IPA draws the average score of the Importance and Performance of the service attributes in a two-dimensional graph. The vertical axis represents the Importance and the horizontal axis represents the Performance, as Figure 1 shows ${ }^{15-19}$.

Each of the four quadrants of the IPA approach has its own definition [21-24]:

1) Keep up the good work: this means that customers attach great importance to the service quality programs of this quadrant and are satisfied with the service performance of the businesses. Therefore, service quality programs in this quadrant belong to "Keep up the good work".

2) Concentrate here: this means that customers attach great importance to the service quality programs of this quadrant, but they are not satisfied with the service performance of the businesses. Therefore, service quality programs in this quadrant belong to "Concentrate here".

3) Low priority: this means that customers don't attach great importance to the service quality programs of this quadrant and are not satisfied with the service performance of the businesses. Therefore, service quality programs in this quadrant belong to "Low priority".

4) Possible overkill: this means that customers don't attach great importance to the service quality programs of this quadrant, but they are satisfied with the service performance of the businesses. Therefore, service quality programs in this quadrant belong to "Possible overkill".

With the division of different quadrants, the managers can make the best use of limited resources, distinguish the advantages and disadvantages in the market competition and determine improvement priorities so as to increase customer's satisfaction. IPA approach can easily demonstrate the service 
quality attributes and the improvements[25-27]. It is widely used by many scholars in other fields as the tool of analyzing the priorities of quality improvements and satisfying customers' demands[28,29].

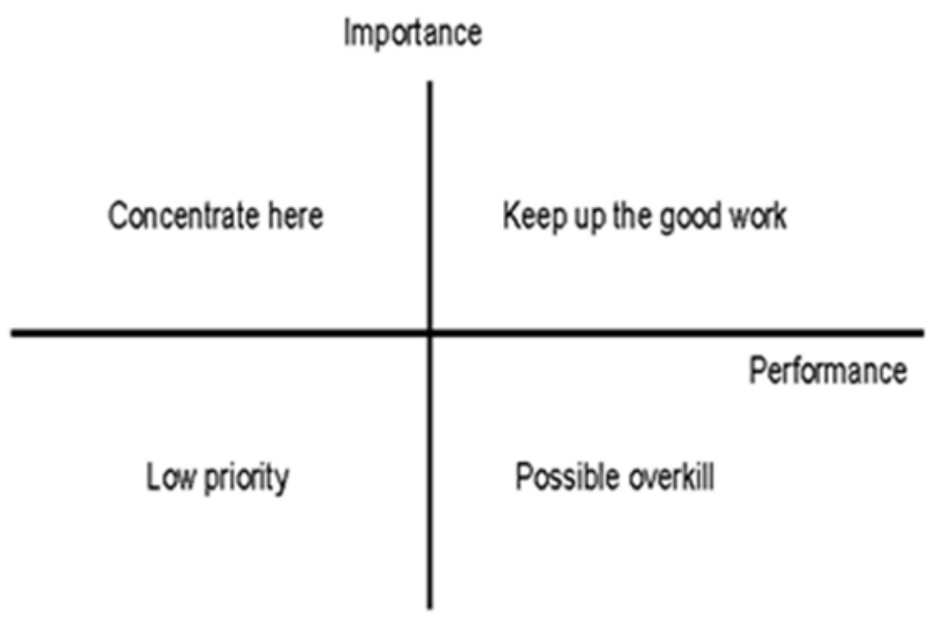

Figure 1 IPA Chart

\section{Research Results and Discussion}

Company A is the top $3 \mathrm{~B} 2 \mathrm{C}$ shopping site in Taiwan. This study takes company A as a case to study its service quality and competitive strategy. This questionnaire uses the 7-point Likert Scale and has nine measurement indicators. A total of 465 questionnaires were distributed among the consumers of the shopping site and 358 valid questionnaires were collected. The effective collection rate was $76.99 \%$. This study uses the average value of Importance (5.83) and the average value of Performance (5.69) as the standard coordinates to judge the performance of each indicator. Please see Table 1 for details.

Table 1 Measurement of the Service Quality of the Online Bank and Competitive Strategy

\begin{tabular}{|c|c|c|c|c|}
\hline No. & Question & Importance & Performance & $\begin{array}{l}\text { Competitive } \\
\text { strategy }\end{array}$ \\
\hline 1. & $\begin{array}{l}\text { Easy to find the } \\
\text { information needed on the } \\
\text { website }\end{array}$ & 5.5 & 5.6 & Low priority \\
\hline 2. & $\begin{array}{l}\text { Quick to complete } \\
\text { transactions on the website }\end{array}$ & 5.4 & 5.5 & Low priority \\
\hline 3. & The website is easy to use & 6.0 & 5.6 & Concentrate here \\
\hline 4. & $\begin{array}{l}\text { The website has been } \\
\text { operating in normal status }\end{array}$ & 6.1 & 6.1 & $\begin{array}{l}\text { Keep up the } \\
\text { good work }\end{array}$ \\
\hline 5. & $\begin{array}{l}\text { The products sold by the } \\
\text { website are genuine }\end{array}$ & 5.9 & 5.9 & $\begin{array}{l}\text { Keep up the } \\
\text { good work }\end{array}$ \\
\hline 6. & $\begin{array}{l}\text { The products will be } \\
\text { delivered accurately with } \\
\text { clear commitment }\end{array}$ & 6.1 & 5.8 & $\begin{array}{l}\text { Keep up the } \\
\text { good work }\end{array}$ \\
\hline 7 & $\begin{array}{l}\text { Compensation for } \\
\text { transactions with problems }\end{array}$ & 5.7 & 5.8 & Possible overkill \\
\hline 8 & $\begin{array}{l}\text { The website will protect } \\
\text { relevant information of } \\
\text { online shopping }\end{array}$ & 5.9 & 5.6 & Concentrate here \\
\hline 9 & $\begin{array}{l}\text { The website will not share } \\
\text { personal information with } \\
\text { other websites }\end{array}$ & 5.9 & 5.3 & Concentrate here \\
\hline Average & & 5.83 & 5.69 & \\
\hline
\end{tabular}


The research shows: (4) The website has been operating in normal status; (5) the products sold by the website are genuine; (6) the products will be delivered accurately with clear commitment. The three indicators belong to "Keep up the good work". They are the merits of the service quality of company A, which shall be kept up so as to maintain good service performance.

(7) Compensation for transactions with problems, this indicator belongs to "Possible overkill". The performance of company A is good, but it cannot bring more service satisfaction. Company A should consider to transfer the company's resources to other competitive indicators.

(1) Easy to find the information needed on the website and (2) quick to complete transactions on the website, these two indicators belong to "Low priority". These two service quality indicators can be improved when company A has more resources.

(3) The website is easy to use; (8) the website will protect relevant information of online shopping; (9) the website will not share personal information with other websites. Company A has competitive disadvantages in the three indicators, which belong to "Concentrate here". Company A must concentrate resources to enhance the service quality and performance of the three indicators. Only in this way can it reverse disadvantages and enhance competitiveness.

\section{Conclusion}

The competition of online shopping market is very intense, so businesses should determine their market positioning and segment accurately, avoid the imitation of products or business model so as to establish unique competitive advantages. The most important thing for businesses is to understand consumers, evaluate the service quality factor of online shopping and satisfy customers' demands. This study uses the IPA approach to analyze the service quality of online shopping provided by the case company, introduces nine indicators to measure the service quality of online shopping and puts forward suggestions for the competitive strategy as the basis for the improvement of competitive strategy of the case company.

\section{References:}

[1] Zwass, V. (1991). Electronic commerce: structures and issues. International Journal of Electronic Commerce, 1(1), 3-23.

[2] Koleser, M.B., \& Galbraith, R.W. (2000). A services-marketing perspective on e-retailing: Implications for e-retailers and directions for further research. Internet Research: Electronic Networking Applications and Policy, 10(5), 424-438.

[3] Zeithaml, V.A., Parasuraman, A., \& Malhotra, A. (2002). Service quality delivery through web sites: A critical review of extant knowledge. Journal of the Academic of Marketing Science, 20(4), 362-375.

[4] Rust, R.T., \& Kannan, P.K. (2003). E-Service: A new paradigm for business in the electronic environment. Communication of the ACM, 46(6), 37-42.

[5] Wymbs, C. (2000). How electronic commerce is transforming and internationalizing the service Industries. Journal of Services Marketing, 14(6), 463-479.

[6] Zeithaml, V.A., Parasuraman, A., \& Malhotra, A. (2002). Service quality delivery through web sites: A critical review of extant knowledge. Journal of the Academic of Marketing Science, 20(4), 362-375.

[7] Parasuraman, A., Zeithaml, V.A., \& Malhotra, A. (2005). E-S-QUAL: A multiple-item scale for assessing electronic service quality. Journal of Service Research, 7(3), 213-233.

[8] Martilla, J. A. \& James, J. C. 1977. Importance-Performance Analysis. Journal of Marketing, 41 (1), 77-79.

[9] Guo, J.J. and Tsai, S.B. 2015. Discussing and Evaluating Green Supply Chain Suppliers: A Case Study of the Printed Circuit Board Industry in China. South African Journal of Industrial Engineering, 2015, 26(2), 56-67.

[10] Tsai, S.B., Huang, C.Y., Wang, C.K., Chen, Q., et al. 2016. Using a Mixed Model to Evaluate Job Satisfaction in High-Tech Industries. Plos One, 2016, 11(5): e0154071. 
doi:10.1371/journal.pone.0154071

[11] Martilla, J. A. \& James, J. C. 1977. Importance-Performance Analysis. Journal of Marketing, 41 (1), 77-79.

[12] Lee, Y.C., Chu, W.H., Chen, Q., Tsai, S.B., et al. 2016. Integrating DEMATEL Model and Failure Mode and Effects Analysis to Determine the Priority in Solving Production Problems. Advances in Mechanical Engineering, 2016, 8(4), 1-12.

[13] Tsai, S.B., Xue, Y., Zhang, J., Chen, Q., et al. 2016. Models for Forecasting Growth Trends in Renewable Energy. Renewable \& Sustainable Energy Reviews, 2016, DOI: 10.1016/j.rser.2016.06.001.

[14] Qu, Q., Chen, K.Y., Wei, Y.M., et al. 2015. Using Hybrid Model to Evaluate Performance of Innovation and Technology Professionals in Marine Logistics Industry Mathematical Problems in Engineering, 2015, Article ID 361275, 8 pages, http://dx.doi.org/10.1155/2015/361275.

[15] Zhou, J. Wang, Q., Tsai, S.B., et al. 2016. How to Evaluate the Job Satisfaction of Development Personnel. IEEE Transactions On Systems Man Cybernetics-Systems, 2016, 10.1109/TSMC.2016.2519860.

[16] Tsai, S.B., Li, G., Wu, C.H., Zheng, Y., et al. 2016. An empirical research on evaluating banks' credit assessment of corporate customers. SpringerPlus, 2016, 5:2088. DOI 10.1186/s40064-016-3774-0.

[17] Su, J. M., Lee, S. C., Tsai, S. B. \& Lu, T. L. 2016. A comprehensive survey of the relationship between self-efficacy and performance for the governmental auditors. SpringerPlus, 2016, 5:508. DOI 10.1186/s40064-016-2104-x.

[18] Tsai, S.B., Lee, Y.C. \& Guo, J.J. 2014. Using modified grey forecasting models to forecast the growth trends of green materials. Proceedings of the Institution of Mechanical Engineers, Part B: Journal of Engineering Manufacture, 2014, 228(6): 931-940.

[19] Tsai, S.B., Chen, K.Y., Zhao, H., Wei, Y.M., et al. 2016. Using a Mixed Model to Explore Evaluation Criteria for Bank Supervision: A Banking Supervision Law Perspective. PLoS ONE, 2016, 11(12): e0167710. doi:10.1371/journal.pone.0167710

[20] Chen, H.M., Wu, C.H., Tsai, S.B., Yu, J., et al. 2016. Exploring key factors in online shopping with a hybrid model. SpringerPlus, 2016, 5:2046. DOI 10.1186/s40064-016-3746-4.

[21] Deng, X.Y., Hu, Y., Deng Y. \& Mahadevan, S. 2014. Environmental impact assessment impact assessment based on numbers. Expert Systems with Applications, 2014, 41 (2), 635-643.

[22] Wang, J., Yang, J., Chen Q. \& Tsai, S.B. 2016. Collaborative Production Structure of Knowledge-sharing Behavior in Internet Communities. Mobile Information Systems, Article ID 8269474, 9 pages, http://dx.doi.org/10.1155/2016/8269474.

[23] Wang, J., Yang, J., Chen Q. \& Tsai, S.B. 2016. Creating the Sustainable Conditions for Knowledge Information Sharing in Virtual Community. SpringerPlus, 5:1019, DOI 10.1186/s40064-016-2702-7.

[24] Lee, Y.C., Wang, Y.C., Chien, C.H., Wu, C.H., et al. 2016. Applying Revised Gap Analysis Model in Measuring Hotel Service Quality, SpringerPlus, 5:1191, DOI 10.1186/s40064-016-2823-z.

[25] Lee, Y.C., Wang, Y.C., Lu, S.C., Hsieh, Y.F., et al. 2016. An Empirical Research on Customer Satisfaction Study: A Consideration of Different Levels of Performance. SpringerPlus, 5:1577, DOI 10.1186/s40064-016-3208-z.

[26] Chin, T., Tsai, S.B., Fang, K., Zhu, W., et al. 2016. EO-Performance relationships in Reverse Internationalization by Chinese Global Startup OEMs: Social Networks and Strategic Flexibility. PLoS ONE, 11(9): e0162175, doi:10.1371/journal.pone.0162175.

[27] Lee, S.C., Su, J.M., Tsai, S.B., Lu, T.L., et al. 2016. A comprehensive survey of government auditors' self-efficacy and professional Development for improving audit quality. SpringerPlus, 5:1263, DOI 10.1186/s40064-016-2903-0.

[28] Chen, H.M., Wu, C.H., Tsai, S.B., Yu, J., et al. 2016. Exploring key factors in online shopping with a hybrid model. SpringerPlus, 5:2046, DOI 10.1186/s40064-016-3746-4. 
[29] Ge, B., Jiang, D., Gao, Y., \& Tsai, S.B. 2016. The Influence of Legitimacy on a Proactive Green Orientation and Green Performance: A Study Basedon Transitional Economy Scenarios in China. Sustainability, 8, 1344, 1-20. doi:10.3390/su8121344. 